\title{
ПЕТРОФИЗИЧЕСКОЕ МОДЕЛИРОВАНИЕ ОСАДКОВ, СОДЕРЖАЩИХ ГАЗОВЫЕ ГИДРАТЫ
}

Бочарова A.A.

(МТУ ии Ломоносова)

Актуальность изучения толщ морских осадков, содержащих скопления газовых гидратов обусловлена, с одной стороны, необходимостью учитывать распространение осадков, содержапих газовые гидраты и больпое количество свободного газа, при проектировании и строительстве подводных сооружений (буровых платформ и т.д.), а с друтой стороны, тем, что газовые гидраты уже многие годы рассматриваются как перспективный источник энергин. Одним из нанболее удобных методов решения указанной задачи (исследования распространения газовых гидратов) является сейсморазведка. Для корректного истолкования получаемых при сейсмических исследованиях данных необходимо опираться на результаты моделирования зависимостей упругих характеристик породы от ее петрофизических параметров (литологии, пористости, насыщения). Поэтому целью настоящей работы является построение сейсмогеологической модели, хорошо описывающей морские осадки, содержапие газогидраты и анализ динаминеских характеристик отражений на границе между осадком содержащим газ и осадком того же литологического типа, но содержащим газовые гидраты вместо газа.

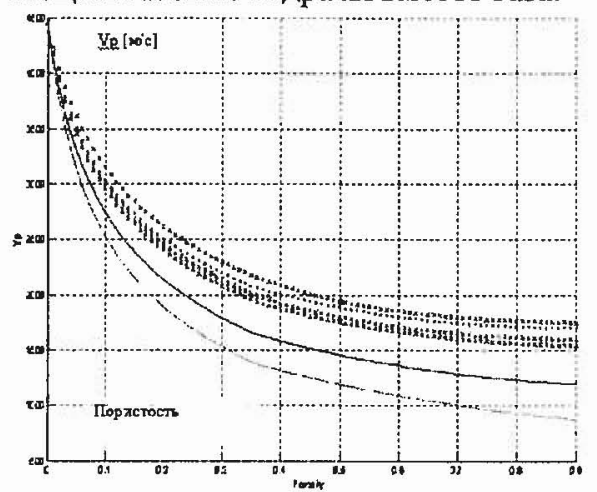

Рис. 1. График зависимости скорости продольных волн от пористости с различными вариантами насыщеншя осадка газовым гидратом.

В рамках данной работы рассмотрено моделирование на основе теории Герца-Миндлина-ХашинаШтрикмана, впервые описанное в статье «Estimating the amount of gas hydrate and free gas from marine seismic data) (Christine Ecker, Jack Dvorkin, and Amos M. Nur). Преимущества данного подхода состонт в том, что он позволяет учитывать все основные параметры породы: тип гранулярной упаковки, степень уплотнения осадка, соотношение минеральных компонент и флюида. В работе исследованы теоретические зависимости упругих характернстик породы от пористости, насьщения, глубины залегания, литологин коллектора для случаев, когда газовый гидрат входит в состав порового флюида или в состав минерального скелета.

На рис. 1 пунктирные кривые построены в предположении, что газовые гидраты являются частью порового флюида, а крестиками, - что газовый гидрат - часть твердого минерального скелета. Цветами показано насыщение гидратом: синяя - $30 \%$

газового гидрата в породс, фиолетовая - 10\%, а красная - 0\% (т.е. порода без гидрата). Сплошная кривая описывает породу, содержашую газ вместо газового гидрата. Синяя кривая отвечает газонасыщению в $3 \%$, зеленая - в $10 \%$. Минеральный скелет в изначально состоял из $60 \%$ кварцевого песчаника и $40 \%$ глин.

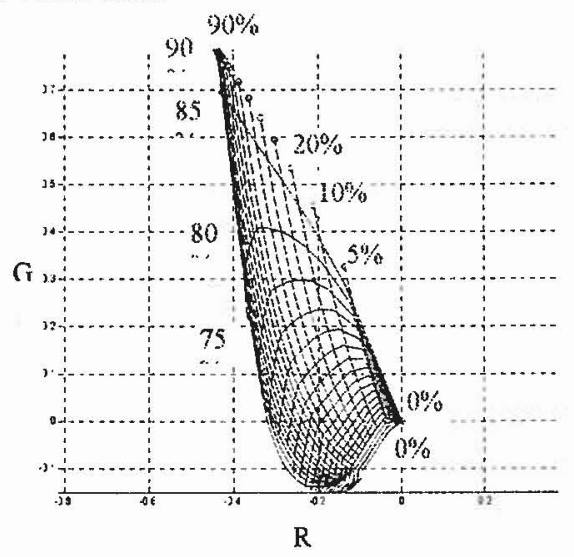

Рис. 2. Диаграмма линий равного насыщения гидратом от $0 \%$ до $90 \%$ с шагом $5 \%$ (зелењый цвет) и линий равной пористости осадка от $0 \%$ до $90 \%$ с шагом $5 \%$ (красный цвет) в осях AVOинтерсепт - AVO-градиент.

Как видно, наличке гидрата приводит к увеличению скорости продольньх волн, при этом в случае, когда газовый гидрат-часть минерального скелета, скорость выше, чем в случае, когда газовый гидраг-часть порового флюида. Разница между этими кривыми растет с увеличением насыщения породы гидратом. Так как газовые гидраты образуются и сохраняют свою структуру только при определенных термобарических условиях, ниже зоны стабильности газовых гидратов может находиться свободный газ. Контраст в акустических свойствах осадка, насышенного газовым гидратом и газом может послужить причиной появления на сейсмических разрезах нелитологической границы (BSR). В данной работе зта граница является объектом AVOмоделирования, как граница между двумя полупространствами, состоящими из пород одинакового литологического состава, насыщенных газовым гидратом в верхнем полупространстве и газом в нижнем. Для этой границы были рассчитаны AVO-атрибугы. Состав минерального скелета осадка: $60 \%$ кварцевого песчаника, $40 \%$ глин, глубина верхней границы зоны осадков с газогидратами - 200 м под морским дном. С увеличением пористости уменьшаются значения Ro, с увеличением насыщения увеличиваются значения Gr.

Данная работа позволяет сделать следующие выводы:

Вопрос об отнесении гидрата к жидкой фазе или к минеральному скелету является достаточно важным, так как влияет на результаты AVO-моделирования.

Использование техники AVO-анализа на границе BSR может быть использовано для изучения свойств породы, вмещающей эту гранищу. 